\title{
Intellectual property
}

\section{5. 'I have a patent lawyer on my payroll': Intellect v intellectual property rights - a battle over the cultural commons}

\section{ABSTRACT}

Over the last 20 years, markets have come to dominate the way 'resources' are managed. The expansion of the market doctrine has at its core the belief that appropriate private property rights are the best way to promote innovation and protect freedoms. The scramble over private property rights is now well entrenched in the intellectual property arena, with countless examples of patents entering areas that once seemed inconceivable. This article moves from Bollier's (2002) discussion of the concept to argue that intellect, rather than being a commodity that is promoted by private property rights, is rather a commons - more specifically a 'cultural commons'. As such, the process of commodification turns intellect into intellectual property - limiting its availability. As a commons, if intellect is to be promoted, it must be open and shared in the public sphere. In contrast to the ongoing commodification of all aspects of life, social movements and academics are beginning to rediscover the commons. This rediscovery now takes the battle between the dominant forces of free market fundamentalism and those who oppose them, into the cultural sphere.

JAMES ARVANITAKIS

University of Technology, Sydney 


\section{Introduction}

T NTELLECTUAL property is defined by IP Australia, the Australian Government's agency responsible for granting rights in patents, trade marks and designs, as representing 'the property of your mind or intellect. In business terms, this also means your proprietary knowledge' (emphasis added). Intellectual property can be anything from an invention, trademark, 'original design or the practical application of a good idea' (IP Australia, 2003).

For proponents of intellectual property, it is a key component of success in business today. It is seen as 'the edge which sets successful companies apart', and is essential in protecting what is considered to be 'your' property in an environment where world markets have become increasingly competitive (IP Australia, 2003).

Intellectual property rights are part of the wider property rights that have come to define one of the key organising principles of modern economies, that also include real property (such as land and buildings) and financial property (such as shares) (McTaggart et al, 1999). Such property rights allow owners to use, disperse, sell, trade and profit from their intellectual property. In this way, it is argued that intellectual property rights are essential in promoting further innovation and progress, they provide financial rewards and incentives to the owners (ibid.). If not enforced, the argument proceeds, there is little incentive and effort placed into the development of knowledge, as people spend all their time protecting their property.

The freedom to establish and trade property rights is central in free market economies. In fact, such market freedoms have been extended to represent wider human freedoms more generally (Bollier, 2002: 23). For example, in a speech honoring free market economists, the US President, George W. Bush, argues that free markets also represent the freedom of people (Bush, 2002).

Intellectual property is thus seen to be like any other commodity that can be traded. If the basic laws of 'supply and demand' economics that characterises the trade of commodities are extended to intellectual property, the scarcer are such commodities the higher will be their value. The owner of the commodity has the right to withhold the use of the intellectual property, and unless appropriately compensated, can seek legal action and financial damages from those who use their 'property' without an agreed level of compensation - which is usually financial.

As intellectual property rights have become a key organizing institution in 


\section{THE PUBLIC RIGHT TO KNOW}

modernity, the principle is rarely challenged (Bollier, 2002). For it makes perfect 'sense' that if someone invents an idea, then they have the right to claim it as their own, and as such, prevent or charge others to use it. Without such rights, the incentive to develop further knowledge diminishes.

In contrast to the position that intellectual property rights enhance knowledge, many argue that this actually has the opposite effect. That is, intellectual property rights actually stifle research and knowledge development (Bollier, 2002). For this process of commodifying knowledge turns intellect, the development and free sharing of knowledge, into a commodity that is witheld unless its 'owner' receives appropriate compensation. This process is increasing in both speed and reach, and appears to be a logical extension of today's implementation of the neo-liberal agenda. Despite the ongoing dominance of this position, oppositional movements are growing that challenge the expansion of the markets in this way (Klein, 2001a).

This paper argues that rather than understanding the development of knowledge as being driven by the application of intellectual property, it should be seen as driven by the free sharing of 'intellect'. Intellect is not a commodity that is 'owned' by any individual, but something that is developed, enhanced and freely shared by a wider community - however defined. In contrast to treating knowledge as a scarce commodity, this process makes intellect abundant. As such, this means that rather than being a commodity, intellect needs to be understood as a 'commons'.

\section{Understanding the commons}

Both the term and the concept of 'the commons' are something that is unfamiliar within our modern world and language (Bollier, 2002). While housing prices and the direction of the share market appear to dominate an ever-increasing portion of our consciousness, our market culture seems to encourage little belief that we have things in common (Bollier, 2002: 8). Despite this, there are many things that are 'common' and shared - both physical and cultural. These are defined as the commons. Before discussing 'intellect' as a common, it is important that the concept be elucidated.

Reid (1995: 29) defines the commons as physical-shared environmental resources such as a forest, the atmosphere, fisheries or grazing land. But today, the commons need to be understood within both the cultural and political spheres. These are the areas that society shares - the need for safety, trust, cooperation, shared intellect, human relationships and so on. That is, the very 
foundations of what makes our society such, rather than a group of individuals living in close proximity to each other.

The Ecologist (1996: 6) offers a more appropriate definition: 'the commons is the social and political space where things get done and where people have a sense of belonging and have an element of control over their lives', providing 'sustenance, security and independence' (ibid: 7). The commons is understood to be ubiquitous, and function all the time and everyday (ibid: 7).

The commons has a number of definitive characteristics. The first is that true commons cannot be commodified - and if it is - it ceases to be commons. The second aspect is that while it is neither public nor private, The Ecologist (1993: 9) claims that it tends to be managed by local communities. While this may be true to a degree, commons cannot be exclusionary. That is, they cannot have borders built around them otherwise they become private property. The third aspect of the commons is that, unlike resources, they are not scarce (Ecologist, 1993: 9). In fact, if managed properly, they work to overcome scarcity.

Thus, while there are physical (environmental) and institutional commons (such as public education), it is argued here that there are also social or cultural commons. Elsewhere I have defined the cultural commons to also include trust, hope and safety, but it is 'intellect' that is the focus of this paper (see Arvanitakis, 2003). Here, intellect is defined as the open sharing of ideas that is not driven by commercial gain. Thus, it ranges from research material freely available on the internet, to the open discussion of research and ideas at conferences. Intellect is shared with no commercial transaction undertaken. The sharing of intellect is inclusionary as the wider community is welcomed.

\section{Intellect not intellectual property}

To better interrogate this concept, we can use the sharing of intellect amongst academic communities (which Bollier (2002: 135) describes as the 'academic commons'). According to Bollier, only a generation ago, academic researchers regarded the patenting of their discoveries as unseemly - a contemptible affront to the mission of science. Bollier (ibid.) outlines a number of examples where researchers refused to patent either their discoveries or techniques, including John Salk, Albert Sabis and John Endes who did not seek to claim ownership of their polio vaccine.

Importantly, Bollier (ibid.) does not paint these scientists as either saintly or naive, but argues that the basis of academic community and knowledge 


\section{THE PUBLIC RIGHT TO KNOW}

formation is the free exchange of ideas, research tools and data to allow for peer review, rigor, ethics and scrutiny. This type of exchange builds a bond of reciprocity and interaction that, according to Georg Simmel (1950: 392), builds a community of gratitude free from any threat of external coercion.

This is the intellect that is shared amongst our community of academia. However, all our research can only exist by acting as a 'building block' upon the work of our peers - though possible, knowledge rarely emerges randomly or in isolation. Knowledge is expanded by the critical feedback received, both positive and negative, that emerges from our peers who review and discuss our work free of charge. This non-commercial process works to enhance our work and the general intellect. This is not only my intellect, but (hopefully) that of the academic community, and even possibly, that of the wider society. Thus, if intellect is treated as a common, it is openly shared, non-exclusionary and is available in abundance, rather than being a scarce commodity.

In this way, it is argued here that the commons of intellect represents one of the foundations of both the academic and wider community. Community is established this way by the process of 'gift giving' - that is, non-commercial transactions that are based on trust and reciprocity (Bollier, 2002). This position builds on the work undertaken by Marcel Mauss, who argued that it is the process of gift giving that is central in the building of communities.

Attempts to define community have been the source of many debates. For example, Young (1986), Mouffe (1999) and more recently Tanesini (2001) have continued a debate around the issue of exclusion and community. Much of the concerns here are focused around the contention that any 'us' excludes a 'them'.

However, by viewing community from the looking glass of the cultural commons, we gain an alternative perspective. For as the definition suggests, true commons are not exclusionary, but rather if shared, become more abundant. Further, 'communities' can be established both locally and globally - existing in any space and at any time. Again the 'academic community' provides an example: I do not just belong to the institution that I may be physically located, but rather a wider discipline that is located throughout the world and with links to the past, and (hopefully) to the future.

The commons of intellect provides an alternative to understanding how the academic community functions. While it does not dismiss the concept of ownership, it does argue that intellectual property must be considered as a secondary factor when considering the expansion of knowledge. 
Despite this, the commons is something that is either dismissed or rarely considered in policy making. As stated, today it is argued that only appropriate property rights, rather than common ownership, can promote innovation. This is based on the belief that commons, if left to the device of 'human nature', invariably leads to them being neglected or abused - something described as the 'tragedy of the commons' (Hardin, 1968).

\section{The tragedy of the commons}

In Garret Hardin's (1968) original work, the concept of the 'tragedy of the commons' is focused on the physical (environmental) commons. Based on the broad belief of 'methodological individualism' (Jacobs, 1994), Hardin (1968) argues that humanity inevitably exploits the commons. He concludes that 'the survival of the commons depends on "mutual coercion mutually agreed on"" (Reid 1995: 29). Hardin (1968) argues that an administrative elite should undertake this, though today's neo-liberal capitalism offers us 'the market'. It is important to draw the link here with Sklair's (1996 and 2000) Transnational Capital Class (TCC). These are those elite managers, policy advisers and politicians that actively promote the agenda of neo-liberal solutions to all areas including the environment. Here, Hardin's administrative elite seems replaced by the TCC who offer the markets as the means to better manage the commons.

Today, much of what has traditionally been thought of as the commons has disappeared. There is very little left in our world that is shared, as there seems to be little understanding of anything that does not rely on defined private property rights (Jacobs, 1994). In fact, the majority of economic textbooks state that if private property rights cannot be defined then we are witnessing market failure (for example, see MacTaggart et al, 1999 for a one-dimensional perspective on this topic).

The logic is that a lack of private property rights means that the 'resources' are subject to constant dispute and potential conflict. The natural extension of this concept is to commercialize the commons - run them like a business otherwise they will be neglected. For example, recent discussions about the soil salinity around Australia's rivers prompted leading corporate figures to demand that Australia's rivers be run 'like a business' (Peatling, 2002: 8).

This is a re-occurring theme in much of the neo-liberal literature, as it is often argued, that 'privatisation of these global commons might just be the future of conservation' (Pearce, 2002: 10). A 2002 report from Britain's Royal Society (quoted in Pearce, 2002: 10), criticizes government run conservation 


\section{THE PUBLIC RIGHT TO KNOW}

programs, development aid, protected areas and even gene banks, and claims that it is time 'for capitalism to take charge' (Pearce 2002: 10). According to the report, the environment should be 'parceled out to the private sector, with market forces influencing everything from cleaning up our rivers and atmosphere to protecting forests and soils' (ibid.).

We have also seen a similar approach taken to the academic community. The growing number of business/university relationships is turning students into 'consumers, education into training for jobs, professors into hired out consultants and researchers, and campuses into corporate research and profit centers' (Dugger, 2000).

It is also the trend that is emerging with the proposed changes to the Nelson Review. New research by the National Tertiary Education Union (NTEU) has found that the Government is not appropriately funding the universities, and that this lack of funds will be promulgated with the proposed Nelson Review (NTEU 2003a). As such, this will further force universities to seek private funding. Carolyn Allport, president of the NTEU, noted that the focus is to further promote private funding for universities, rather than maintaining or increasing public funding (NTEU 2003b). By placing the emphasis on private funding, it would appear that 'the Government has raised the white flag, and is saying that it no longer accepts responsibility for ensuring that universities are properly funded' (ibid.). Thus, the implication is clear. Universities are unable to function independently and now must be run 'in a business like fashion' (Nelson, 2003). This change means that the once public institutions (or institutional commons) are now becoming centers for private research.

Just as importantly however, are the cultural implications that the community cannot manage communally based resources. This type of argument contains a clear logic - a clear cultural statement - that 'human nature' means we are 'greedy', and as such, we must be protected from ourselves or all resources, both physical and institutional, will disappear. The source of the problem is human nature, which can only be disciplined by market forces and the profit motive.

\section{Commons under neo-liberalism}

For the commons, life under neo-liberalism is precarious. Neo-liberalism works to enclose the commons, and thus turn them into commodities. While there has always been a tension between the commons and the market, markets have exploded and we are seeing the commodification of everything. The end 
result has been that we no longer even recognize the existence of commons (Bollier 2002: 6). For what makes this so different to other times in history is the vast imbalance between the market and democratic polity (Barber 1998). The market is asserting its domination over everything, which is eroding our sense of community (Bollier, 2002: 6).

Today's dominant economic theory as represented by neo-liberalism specifically focuses on the on the individual not the collective. Radin (1996) argues that the dominance of this ideology means that the market believes everything has a price and can be traded. Any attempt to control this, is seen as 'paternalistic and interfering in free decisions' (Bollier 2003: 24). Thus, the market relies on everything being for sale as the language 'of commodification affects a timeless objectivity' (ibid.).

Property interests and the radical application of copyright and patent laws are rapidly carving up the public domain of intellect. Therefore, we see a battle between intellect and intellectual property rights. This has most notably been highlighted in debate over the Trade Related Intellectual Property (TRIPs) agreement, which sits within the auspices of the World Trade Organization. These negotiations have not only limited access to medicines for pandemics such as HIV/AIDS, but also the use of these agreements is moving to limit the research and development of medical breakthroughs more generally.

For example, it has been reported that genetic research organizations have begun placing patents over any 'diagnostic or therapeutic use of BRCA1 and BRCA2 and the proteins that they code for' (Westphal, 2002: 29). These are the genes that assess a woman's risk of breast or ovarian cancer. The result is that 'a big biotechnology company (in this case Myriad) with its two key genes, [are] going around the world telling small diagnostic labs they can't test people any more because the genes are private property' (ibid.).

Westphal points out that others are starting to copy Myriad's example, setting a far reaching precedent that life forms themselves can be claimed as private property despite the fact that these genes belong to each human individually. Similarly, this process ignores the great deal of work over a number of years undertaken in the field that has led to this 'discovery'. Westphal's investigative report published by the New Scientist, noted that the aims of biotechnology organizations are to obtain a monopoly of certain genes: 'there are now numerous patent applications for key cell receptors that claim their associated genetic sequences and mechanisms of actions' (ibid: 29).

This type of action moves towards breaking down the possibility for (the 


\section{THE PUBLIC RIGHT TO KNOW}

cultural commons of) intellect. Westphal notes that soon 'after being granted the US patents in the mid-1990s, Myriad successfully halted most testing being done by the labs in the US' (ibid: 30). Though the road that Myriad has traveled has not been without direct challenge, the organization has been successful in establishing borders (in this case intellectual property rights) where there once existed a world that did not recognize them. Despite the rhetoric that appropriate private property rights are required to promote research, Westphal (2002: 30) notes that: 'Generally speaking, it's widely acknowledged that once someone patents a gene, researchers interested in finding diagnostic tests or therapies based on that gene will shy away from it for fear of infringing the patent.'

In this way, the abundance of intellect is turned into a scarce commodity. The move to limit the use of intellect works to engulf the commons, and erode the sense of community. This aspect of current neo-liberalism means that it is reaching into the very cultural interactions of our society. There appears very little that is isolated from commodification and kept for the common good. Here, the rule and law of the market appears to be creating a new great transformation that reaches well into the cultural sphere.

Legal precedents appear to continually set individual property rights over communal rights - something that also seems to be the essence of the TRIPS regime. Farhat (n.d.) provides a number of examples where patents and restrictions have been placed on foodstuffs; moving seeds from the public domain to the private sphere. Thus we have seen seed saving replaced by gene banks. This attempts to limit both the availability of the seeds and further research in this area. Farhat argues that this essentially 'manufactures scarcity' (ibid.).

The continued growth in patent and copyright law has far wider implications. Geertz (1983) believes the law is not so much a set of norms, but rather a manner of imagining the real. Property law has allowed us to re-image the world (Stienberg, 1995). Therefore, the language of commodification has changed both our perceptions and our real world.

\section{Reclaiming the commons}

In No Logo, Naomi Klein (2001b: 311) describes the battle over 'street culture' that has emerged between corporations and their attempts to commodify it, and the reaction of 'anti-corporate activists'. Here, the streets have become a commodity, both physically (through billboards) and culturally (through the 
cooption of local cultures by the advertising industry). In reaction, protests organized by groups such as Reclaim the Streets (RTS) work to reverse this commodification (ibid.: 32). This conflict presents us with a metaphor in understanding the contest over the commons that is occurring between social movements and neo-liberal capitalism.

In countless 'counter-globalization' protests around the world, protest acts as a symbol. This symbol may be even considered different from the position of the individual protestors, who are reacting against a perceived injustice. The protest, as a theatrical symbol, aims to stop people in the streets, make them think and ask what is going on. Such radical symbols also act to highlight the chasm that exists between the 'everyday world' dominated by neo-liberal capital and the alternative world presented by protestors. But neither do the protestors see themselves 'separated' from this world - only alienated by it. Similar to Szerszynski's (1999) description of the Reclaim the Streets 'actions', the protesters do not just want to be left alone to do their own thing, but actually actively aim to disrupt 'society-as-usual', bringing with them a message.

The alternative vision that the protestors bring represents a different way of 'doing' politics that aims to be inclusive. This is a new political space that is established based on opening up new commons. This includes both the physical commons, such as the fight for more public space, as well as in the cultural commons such as overcoming the imposition of intellectual property rights. For example, a number of non-government organizations and social movements have formed coalitions to demand the removal of patents from HIV/AIDS treatments and allow the production of generic drugs (Gunaratnam, 2003). The Kremlin provides another contrasting example, an abandoned warehouse reclaimed by a number of activists and turned into a social centre that is aiming to promote the free exchange of art. (The Kremlin is located on King Street Newtown, and was - opened on 24 August 2003). In this way, new commons are continuously emerging (Ecologist, 1993: 7).

If we combine this vision with that represented by Reclaim the Streets, we see a vision of the world that aims to include rather than exclude. This is a world is based on establishing commons rather than commodities. This is in direct conflict with the process of enclosure of neo-liberal capitalism. Thus the contestation that exists between today's neo-liberal capital and social movements is one over the cultural commons - with each attempting to establish their own vision of community. The conflict can thus be seen as one between 
attempts to establish an inclusive community, compared to an atomized economy (Kingdom, 1992).

However, it is not just 'radical' protests that see the re-establishment of the commons. When academics gather to share their intellect, they establish a new commons as it is not based on any commercial transaction, but rather the free exchange of their work. It is a process of 'gift giving' and reciprocity. Therefore, if I email you a copy of my article, I do not expect payment, but would like to know what you think, receive feedback and also discuss what you have written. This means that from the hackers who share code on the net, to academic meetings, the battle between neo-liberalism and the commons continues.

\section{Conclusion}

One day while walking in the corridor at the University of New South Wales, various posters had appeared advising of a workshop that would assist $\mathrm{PhD}$ candidates to commercialise their research. Presenters would include a patent lawyer, who was to advise students of the complicated processes that they needed to ensure the successful commercialisation of their ideas. This article argues that rather than encouraging further research and an expansion of intellect and knowledge, this process is acting to place commercial boundaries on what was once a common. As such, research and intellect are impeded.

Rather than understanding the world as a group of utilitarian, atomised and one-dimensional individuals, the cultural commons offers an alternative lens in understanding how communities function. This perspective is highlighted by the academic community, which has expanded the knowledge of the wider community by treating its intellect as a common. When a patent lawyer is added to the payroll, not only do the commons become enclosed but so does what we have to offer to the wider community.

\section{Bibliography}

Arvanitakis, J. (2003). Another (niche) marketing opportunity?: The counterglobalisation movement and the cultural commons. Conference paper delivered at Creating Spaces, Australian National University, Canberra, July 2003.

Barber, B. (1998). Democracy at risk: American culture in a global culture, World Policy Journal, Summer 1998.

Bollier, D. (2002). Silent Theft: The Private Plunder of our Common Wealth. New York: Routledge.

Bush, G. W. (2002). President Honors Milton Friedman for Lifetime Achievements, 
www.whitehouse.gov/news/releases/2002/05/20020509-1.html (Accessed August 2003).

Dugger, R. (2000). The struggle that matters most. In White, G.D.(ed.), Campus, Inc.: corporate power in the ivory tower. New York: Prometheus Books, pp 17-27.

Ecologist, The (1993). Whose common future? Reclaiming the commons. London: Earthscan Publications.

Farhat, R. (n.d.). Biopiracy: genetic engineering, life patents and the manufacturing of scarcity. Sydney: AID/WATCH.

Geertz, C.(1983).Local knowledge: further essays in interpretive anthropology. New York: Basic Books.

Gunaratnam, P. (2003). HIV/AIDS prevention, treatment and care for young people. In Arvanitakis, J. (ed.), Highly affected, rarely considered: the impacts of globalization on young people. Sydney: Oxfam Community Aid Abroad.

Hardin, G. (1968). The tragedy of the commons. Chapter 2 in Dryzek, J.S. and Schlosberg, D. (1999), Debating the Earth: The environmental politics reader. New York: Oxford University Press.

IP Australia (2003). What is Intellectual Property? www.ipaustralia.gov.au (Accessed August 2003).

Jacobs, M. (1997). Sustainability and markets: On the neoclassical model of environmental economics, New Political Economy, November 1997, Abigndon, pp 365385.

Kingdom, J. (1992). No Such thing as Society. Bristol: Open University Press.

Klein,N. (2001a). Reclaiming the commons, New Left Review, May-June 2001,pp 8189.

Klein, N (2001b). No logo. Netley, South Australia: Griffin Press.

Mauss, M. (1967). The Gift: Forms and functions of exchange in archaic societies. New York: WW Norton.

McTaggart D., Findley C. and Parkin M. (1999). Economics, 3rd Edition. Melbourne: Addison Wesley Longman.

Mouffe, C. (1999). Deliberative democracy or agonistic pluralism?, Social Research, vol. 66, no.3, fall, pp 745-758.

National Tertiary Education Union (NTEU) (2003a). Press Release 6059, sourced from www.nteu.org.au//news/5391/6059 (Accessed August 2003).

National Tertiary Education Union (NTEU) (2003b) Press Release 3893, sourced from www.nteu.org.au/news/890/3893 (Accessed August 2003).

Nelson, B. (2003). Our universities: backing Australia's future, Press Release, 13 May 2003. (Accessed August 2003).

Radin, M.J. (1996). Contested commodities. Cambridge: Harvard University Press. Pearce,F. (2002). Market forces are the way to save the planet, New Scientist, vol. 175, no.2350, 6 July 2002, p10.

Peatling, S. (2002). Run rivers like a business: Expert, Sydney Morning Herald, 9 October 2002, p 8. 


\section{THE PUBLIC RIGHT TO KNOW}

Reid D.(1997). Sustainable development - An introductory guide. London: Earthscan Publications.

Simmel, G. (1950). Faithfulness and Gratitude In The Sociology of Georg Simmel, translated and edited by Wolff, K., Glencoe, Illinois: The Free Press, pp 379-395. Sklair,L. (1996). Conceptualising and researching the transnational capitalist class in Australia, Australian and New Zealand Journal of Sociology (ANZJS), Vol. 32, No. 2, pp 1-19.

Sklair, L. (2000). The Transnational Capitalist Class. Sydney, London: Blackwell Publishers.

Stienberg, T. (1995). Slide mountain, or the folly of owning nature, Berkeley: University of California Press.

Szerszynski,B. (1999). Performance politics: The dramatics of environmental protest. Since published in Ray, L. and Sayer, A. (eds.), Culture and the Economy: After the Cultural Turn. London: Sage.

Tanesini,A.(2001). In search of community, Radical Philosophy, vol.110, November/ December 2001, pp 12-19.

Westphal (2002). Capture of the genetic market, New Scientist, vol. 175, no.2350, 6 July 2002, p 29.

Young, I. (1986). The ideal of community and the politics of difference, Social Theory and Practice, Vol.12, No.1, Spring 1986, p 1-26.

James Arvanitakis is an academic at the University of Technology, Sydney. He is currently a PhD candidate at the University of New South Wales, where his research focus is the emergence of the global justice movement. A former banker, he now aims to explore the relationship between social change theories and the many social movements on the frontline of reform. This article was presented at the third Public Right to Know (PR2K3) conference at the University of Technology, Sydney, 17-19 October 2003. james.arvanitakis@uts.edu.au 